\title{
Um leitor do teatro português no século XIX
}

\author{
Regina Zilberman
}

Em 1816, o parisiense Ferdinand Denis (1798-1890) deixou a terra natal aparentemente na direção das Índias; acabou, porém, desembarcando no Brasil, onde permaneceu por algum tempo. ${ }^{1}$ Um ano antes, Napoleão Bonaparte (1769-1821) fugira da ilha de Elba, onde estivera aprisionado, retomara o poder sobre a França e enfrentara os exércitos aliados da Inglaterra, Rússia, Prússia e Áustria, comandados pelo Duque de Wellington (1769-1852), que o derrotaram militar e politicamente. A vitória sobre Bonaparte restaurava o domínio da aristocracia conservadora da Europa que, logo a seguir, reunida em Viena, sob a liderança de Metternich (1773-1859), restabeleceu o Ancient Régime, simbolizado pelo retorno dos Bourbons ao trono da França, com a coroação de Luís XVIII (1755-1824), irmão de Luis XVI (1754-1793), decapitado pelos republicanos em 1793.

Durante o apogeu do império napoleônico, a França, inimiga da Inglaterra, declarou o bloqueio continental, buscando impedir que matérias-primas e alimentos chegassem às ilhas britânicas. Derrotado pelo almirante Nelson (1758-1805) na batalha de Trafalgar, em 1805, o general francês julgava poder vencê-lo por meio daquela estratégia econômica. O governo português, dependente financeiramente dos banqueiros londrinos, procurou tergiversar, mas acabou por ter de tomar o partido dos ingleses. Inconformado, Napoleão decidiu invadir aquele país, iniciativa que obrigou a D. João (1767-1826), então regente, a transferir para o Brasil a administração do Estado, acompanhado pela Corte lusitana, permanecendo no Rio de Janeiro até 1821. O exército de Bonaparte alcançou Lisboa em novembro de 1807, retirando-se em 1809. Uma das reações contra os invasores veio na forma de panfletos que, segundo informa Alfredo do Vale Cabral, circularam em grande quantidade na metrópole e na colônia, como o Diálogo entre Lúcifer e Bonaparte, de 1809, ou a Segunda parte da Surriada a Massena e diálogo na França. De Bonaparte enganado, Massena corrido, e um granadeiro resoluto. ${ }^{2}$

Em 1816, talvez o sentimento antinapoleônico já estivesse superado; de todo modo, não se converteu em rejeição aos gauleses, pois, nessa data, chegaram os integrantes da missão artística convidada por D. João para embelezar o Rio de Janeiro. Ferdinand Denis, da sua parte, residiu por seis meses na capital da colônia; na seqüência, dirigiu-se à Bahia, onde trabalhou junto a representantes comerciais da França, que sofriam a concorrência dos ingleses no que diz respeito à troca, entre seus respectivos países e a colônia portuguesa, de produtos naturais e industrializados. ${ }^{3}$

O jovem ficou estabelecido na ainda colônia americana até aproximadamente 1820, quando retornou à sua terra, tendo passando, no caminho, por Portugal. Em 1821, já está de volta em Paris, onde publica, em parceria com o ilustrador Hippolyte Taunay (1793-1864), filho do pintor Nicolas Taunay (1755-1830), membro da missão artística francesa, Le Brésil, ou Histoire, moeurs, usages et coutumes des habitants de ce royame, em seis volumes. 
O conhecimento da língua portuguesa deve ter favorecido a obtenção de outros encargos editoriais, pois, em 1823, traduz obras dramáticas escritas naquele idioma para comporem o volume dedicado a Portugal dentro da coleção Chefs-d'euvre des théâtres étrangers, da editora parisiense Ladvocat.

O proprietário, Pierre-François Ladvocat (1790-1854), dito Camille Ladvocat, era, na época, um dos livreiros e editores mais prestigiados de Paris. Tendo desposado em 1817 a proprietária de uma livraria e de um gabinete literário, fez do local, entre 1815 e 1830, o ponto de encontro dos letrados na cidade. Ladvocat foi também o principal impressor dos românticos, com um catálogo de que faziam parte personalidades como Victor Hugo (1802-1885), Alfred de Vigny (1797-1863), Lamartine (1790-1869) e Chateaubriand (1768-1848), entre outros. Seu prestígio durou até 1830, quando problemas econômicos fizeram-no desfazer-se dos negócios. Honoré de Balzac (1799-1850), em Ilusões perdidas (1837-1843), retratou sua decadência por meio da personagem Dauriat. Ladvocat tinha igualmente grande apreço pela literatura dramática, razão provável da coleção das obras-primas do teatro estrangeiro, que somou 25 volumes.

Encarregado de proceder à seleção das obras oriundas de Portugal, Ferdinand Denis privilegiou dramas de seu tempo, escolhendo a Nova Castro, de João Batista Gomes (c. 1775-1803), A conquista do Peru, tragédia, e Caráter dos lusitanos, tragédia, de Manuel Caetano Pimenta de Aguiar (1765-1832), e Vida do grande D. Quixote de la Mancha e do gordo Sancho Pança, de Antônio José da Silva (1705-1739). Além de traduzir as obras, Ferdinand Denis redigiu a apresentação do volume, que denominou "Notícia sobre o teatro português". Trata-se do primeiro estudo que consagrou à literatura de língua portuguesa, voltado, nesse caso, à dramaturgia, dada a natureza da coleção onde aparece.

Antes de Ferdinand Denis, dois outros historiadores da literatura, estrangeiros como ele, tinham-se debruçado sobre a trajetória histórica da produção literária portuguesa: Friedrich Bouterwek (1765-1828), cuja História da poesia e da eloqüência destinara o quarto volume, publicado em 1805, ao material proveniente de Portugal; e Simonde de Sismondi (1773-1842), que dedicara os últimos cinco capítulos de sua obra, De la littérature du Midi de l'Europe, de 1813, ao mesmo tema. Ferdinand Denis, porém, não se limita a reproduzir o que encontrara nos dois estudiosos; duas outras fontes são significativas e comparecem em sua pesquisa: o Catálogo de los escritores portugueses, elaborado, no século XVII, por Manuel de Faria e Sousa (1590-1649), com 823 entradas; e, principalmente, a Biblioteca lusitana, de Diogo Barbosa Machado (1682-1772), que reuniu, em quatro volumes, impressos entre 1741 e 1759, os dados biográficos e bibliográficos de uma considerável porção de autores lusitanos, atuantes até aquelas datas.

Ferdinand Denis consulta igualmente os ensaios que estudiosos portugueses no final do século XVIII e nas primeiras décadas do século XIX publicavam nos volumes das Memórias de literatura portuguesa, patrocinadas pela Academia Real das Ciências de Lisboa. Dois críticos, principalmente, fornecem-lhe importantes paradigmas de avaliação: Francisco Dias Gomes (1745-1795) e Antônio das Neves Pereira (17??-1818), que, em seus trabalhos, se debruçaram sobre o estilo de Sá de Miranda (1481/1485?-1558?) e de Antônio Ferreira (1528 - 1569), dois dos dramaturgos estudados por Denis. 
As Memórias de literatura portuguesa foram publicadas entre 1792-1814, e Denis deve ter lido pelo menos alguns volumes, já que alude indiretamente aos pareceres dos críticos. Contudo, não menciona o texto de tema similar, a "Memória sobre o teatro português: que contém a sua origem, progresso, decadência e restauração", de Francisco Manuel Trigoso de Aragão Morato (1777-1838), de 1817. Somente quando redige os Resumos da história literária de Portugal e do Brasil, em 1826, aquele ensaio é citado, constituindo um dos principais esteios daquela obra quando o assunto é a dramaturgia lusitana. ${ }^{4} \mathrm{O}$ fato sugere que o trabalho de Morato só veio a ser conhecido depois de publicada a "Notícia", indicando, igualmente, que Ferdinand Denis continuou interessado no tema, prosseguindo os estudos a respeito.

É a Biblioteca Lusitana que oferece a Denis o maior número de informações, sobretudo no que diz respeito à dramaturgia do século XVI. Gil Vicente (1465?-1536?), por exemplo, é autor cuja obra o historiador francês desconhece inteiramente, circunstância que o obriga a repetir os dados biográficos, nem sempre verossímeis ou comprováveis, contidos no verbete que Barbosa dedica àquele escritor. Os parágrafos relativos a Gil Vicente destacam o gênero literário que ele consagrou, o auto, cuja designação aparece em português, dada a ausência de termo equivalente no idioma francês. Além disso, Denis menciona a produção de comédias e tragicomédias, gêneros que comparecem no título da obra organizada pelos filhos do dramaturgo, a Compilaçaõ de todas las obras de Gil Vicente o qual se reparte em sinco livros. O primeiro he de todas suas cousas de devaçam. O segundo as Comedias. O terceiro as Tragicomedias. O quarto as Farsas. No quinto as obras meudas. ${ }^{5}$

Essas são as únicas anotações na "Notícia" dando conta da obra de Gil Vicente, o que chama a atenção por dois aspectos. Indica que, até o começo do século XIX, os portugueses ainda não davam o devido valor ao principal dramaturgo do Renascimento lusitano, que, desde 1502, se dedicava à vida teatral e que correspondia à espontaneidade e ao nacionalismo tão prezados pelo movimento romântico. Talvez por essa razão, alguns anos depois, em 1838, Almeida Garrett (1799-1854), imbuído da tarefa de regenerar o teatro português, tenha escolhido a biografia daquele autor como tema da peça Um auto de Gil Vicente publicada em 1841. Pelo mesmo motivo, até 1834, quando, na cidade de Hamburgo, foram impressas as Obras de Gil Vicente, editadas e corrigidas por José Victorino Barreto Feio (1782-1850) e J. C. Monteiro (1807-?), existia tão-somente a versão de 1562, organizada por iniciativa dos filhos do comediógrafo.

O segundo aspecto relaciona-se ao procedimento de Ferdinand Denis: na "Notícia", ele se refere a Bouterwek, que, na História da poesia e da eloqüência, não apenas dedica um bom trecho ao exame dos autos de Vicente, como também resume a ação do Auto da feira, da Floresta dos enganos e do Auto de Amadis de Gaula, citando trechos dessas peças. Três anos depois, nos Resumos da história literária de Portugal e do Brasil, Ferdinand Denis aproveita essas citações, que comenta e julga, emitindo juízos a partir do conhecimento de segmentos dos textos. Contudo, pode-se supor que, fazendo a apresentação geral de uma antologia que não incluía autos vicentinos, Denis não se preocupe em levar mais adiante o estudo dessa produção. 
Por outro lado, Denis reproduz curiosidades relativas à biografia de Gil Vicente, que formaram, até o século XIX, parte da mitologia relativa àquele escritor, sobre o qual pouco se conhecia. Repete, por exemplo, a informação de que o rei D. João III teria participado de uma das encenações na condição de ator; reitera que a filha de Gil Vicente, Paula, teria sido uma grande atriz, ainda que, na época, as mulheres estivessem proibidas de participar de representações dramáticas. Comenta que um dos filhos do teatrólogo, também denominado Gil Vicente, era excelente escritor; mas que, para evitar a concorrência com o pai, foi enviado para a Índia, onde morreu como herói em uma batalha. Outra anotação extraída do verbete de Diogo Machado Barbosa e corroborada por Denis é a de que o humanista Erasmo (1466-1536), impressionado com o prestígio de Gil Vicente, teria estudado português para ler seus textos.

Se Denis só teve oportunidade de conhecer indiretamente a criação vicentina, ele leu as duas comédias de Sá de Miranda, Os Vilhalpandos e Estrangeiros, sobre as quais faz algumas observações pessoais, bem como discute os comentários que Antônio das Neves Pereira, em um dos volumes das Memórias, consagrou àquele escritor. Ao comentálas, o autor da "Notícia" indica alguns de seus critérios de avaliação das obras: um deles é o estilo, cuja qualidade, destacada por Pereira, reconhece; mas chama a atenção para a importância da ação, cujo desenvolvimento ocupa lugar central em suas avaliações. Dessa maneira, Os Vilhalpandos serão descartados por carecerem de drama, problema que compartilha com Estrangeiros, ainda que Denis encontre "um pouco mais de interesse"6 nessa produção.

Segue-se à referência a Sá de Miranda a relação de cinco outros autores que tiveram alguma relevância no século XVI: Antônio Prestes (?-?); Sebastião Pires (?-?); Antônio Ribeiro Chiado (?-1591); Simão Machado (1570-1640); Jorge Ferreira (1515-1585). Suas informações provêm, na maior parte dos casos, da Biblioteca Lusitana; mas Denis pode ter igualmente consultado a Primeira parte dos autos e comédias portuguesas, coletânea datada de 1587, patrocinada por Afonso Lopes e impressa por André Lobato, onde constam peças de Antônio Prestes, Jerônimo Ribeiro (?-?) e Luís de Camões (1524(?)-1580).

É Antônio Ferreira o primeiro dramaturgo a ter a obra examinada de perto por Ferdinand Denis. Esse destaca primeiramente a Castro, evidenciando o pioneirismo do escritor, ao optar por redigir uma tragédia, gênero que tinha chamado a atenção tãosomente dos italianos. Acompanha a análise daquele drama o esclarecimento dos critérios julgados importantes pelo pesquisador para aquilatar a qualidade de um texto literário. No caso da Castro, sublinha primeiramente o fato de Ferreira, "movido pelo amor à pátria", ter optado por escrevê-la em português, e não em latim ou espanhol, por considerar a língua materna "suscetível de expressar os pensamentos mais nobres". Valoriza também a circunstância de Ferreira ter adotado "assunto nacional", abordado nos termos das regras da tragédia clássica. As duas escolhas podem ter prejudicado a recepção do autor, na avaliação de Denis, para quem Ferreira "soube imitar os antigos com espírito original”, critério, para ele, válido, em contraposição aos contemporâneos do dramaturgo, avessos à forma de composição típica da Antigüidade, que incluía até mesmo o coro, escolha elogiada pelo ensaísta francês, por entendê-la um dos pontos altos da peça. 
Denis aprecia igualmente o estilo de Ferreira; contudo, tal como acontece em relação a Sá de Miranda, aponta para a falta de ação, embora releve o desenho dos caracteres. Porém, não examina a Castro, mas a comédia $O$ cioso. A tragédia terá de aguardar a redação dos Resumos da história literária de Portugal e do Brasil, quando então ocupa um bom trecho do capítulo VII, dedicado ao teatro de Ferreira.

O cioso parece ter constituído uma das preferências de Denis. A peça foi publicada postumamente, em livro em 1622, ao lado das comédias de Sá de Miranda. Denis retirou-a da obscuridade, para estudá-la na "Notícia" e, de novo, nos Resumos da história literária de Portugal e do Brasil. Anos depois, em 1835, traduziu o texto para o francês, estabelecendo a contraditória situação de $O$ cioso consistir em obra quase desconhecida no Portugal do século XIX, enquanto circulava (em que termos não se sabe) no mundo editorial francês.

Denis reconhece que nenhuma das comédias de Ferreira, fosse $O$ cioso, ou Bristo, peça anterior àquela, detém particular destaque na literatura do período. Mas chama a atenção para o fato de que, graças à intriga, a primeira diverte os espectadores, além de pintar um caráter. Sem deixar de salientar alguns erros de concepção, reitera que o texto apresenta boas piadas, misturadas com situações extravagantes, que não aprecia.

O maior mérito de $O$ cioso, segundo Denis, reside na pintura dos caracteres, o que o leva a resumir a intriga da peça e a citar uma das cenas do primeiro ato, reproduzida na "Notícia". Após a sinopse e a citação, o ensaísta fecha suas observações, destacando o "gênio original" de Ferreira; ao mesmo tempo, aponta que a obra de Ferreira corresponde à "infância da arte", sugerindo a concepção de história que adota e que reaparece em outros momentos de seu estudo, conforme a qual a criação literária passa por vários períodos de crescimento, mimetizando de certa maneira a evolução biológica do ser humano.

Ao exame das peças de Ferreira, segue-se o escrutínio da obra dramática de Luís de Camões, restrita a três títulos, dois dos quais - Auto dos Anfitriões e Auto de Filodemo foram, ao contrário do que ocorreu com os poemas, impressos à época em que o poeta vivia. Denis não confere maior atenção a Anfitriōes, imitação de Plauto, conforme ele, e inferior à versão que, cem anos depois, Molière (1622-1673) propõe para o tema. A referência ao comediante francês oportuniza ao ensaísta um comentário que explicita o tipo de diálogo que deseja estabelecer com seu público. Assim, ao afirmar que "o [Anfitriōes] do poeta português serve para provar ainda em que grau nosso Molière se elevou, imitando o autor latino", Denis sugere que lê a literatura portuguesa desde os paradigmas oferecidos pela literatura francesa, conhecida por seus destinatários, a quem deseja apresentar um conjunto de valor equivalente, porém, não igual.

De Camões, Denis escolhe primeiramente o Seleuco, sintetizando a ação e, depois, citando um dos últimos episódios, dominado pela presença do médico que soluciona os problemas amorosos do herói, Antíoco. É compreensível que o resumo da intriga apareça em primeiro lugar, já que, para Denis, a composição da ação é fator primordial para a qualidade de um drama. Justifica a atenção conferida a esse texto também por outra razão: ele quer entender, ou dar a entender para sua audiência, o que é um auto, gênero a que não teve acesso por meio da obra de Gil Vicente. Para além desse ponto não vai sua 
análise, já que considera Seleuco bastante inferior à poesia de Camões, de quem é grande admirador.

Filodemo é igualmente matéria da investigação de Denis, que, outra vez, resume o enredo do auto. A peça não entusiasma o ensaísta, que critica o mau gosto de algumas piadas, observação que já aparecera a propósito de outras comédias do século XVI, como o Bristo, de Antônio Ferreira. Também não aceita a mistura de estilos, já que o Filodemo apresenta alguns trechos em prosa, e outros em verso. A liberalidade do drama do século XVI, anterior às regras que o Classicismo imporia à comédia e à tragédia, especialmente na França de Nicolas Boileau (1636-1711), desagrada o autor da "Notícia”, ainda que esse já tivesse aderido às idéias românticas. Escrevendo, porém, seu estudo antes da revolução promovida no teatro por Victor Hugo - o Cromwell data de 1827 -, Denis provavelmente não poderia pensar de modo muito diferente.

Na seqüência, Denis refere-se aos acontecimentos políticos decorrentes da ação de D. Sebastião (1554-1578), destacando o "jugo espanhol" e a decadência da produção literária. Chama a atenção para o contraditório fato histórico que se estabeleceu: outras nações experimentaram "progressos verdadeiramente prodigiosos" no campo da literatura dramática, enquanto que Portugal, que, logo no começo do século XVI, se antecipara à produção teatral de outros lugares, ficou para trás, em decorrência, conforme o pesquisador, de circunstâncias extra-literárias.

Talvez por essa razão não encontre outro dramaturgo digno de relevância que tenha aparecido no horizonte português após o século XVII. Relaciona uma série de nomes, elencados em ordem cronológica e associados às suas obras mais importantes. $\mathrm{O}$ padre Macedo (1596-1681), que escreveu em latim e circulou na França, é o primeiro deles; segue-se a referência a Antônio José, cuja popularidade, enquanto viveu, é lembrada por Denis. Uma das peças do Judeu faz parte da coletânea francesa, fato sugestivo do apreço por ela por parte do organizador. Este, porém, não deixa de manifestar, na "Notícia”, suas restrições, que, com palavras similares, aparecem em outros historiadores da literatura do período, como Garrett, sinalizando a dificuldade do intelectual do começo do século XIX em lidar com o tipo de teatro popular representado por Antônio José. Assim, critica os problemas de construção da intriga e, sobretudo, condena a vulgaridade encontrada em muitos de seus textos. ${ }^{7}$ Denis reconhece que Antônio José, tal como Gil Vicente, pode ser alcunhado de o Plauto português; mas frisa que talvez o apelido seja indevido, pois, em suas obras, não se desculpam mais as irregularidades de construção, já que a arte dramática teria evoluído ao longo dos duzentos anos que separam os dois autores. Ao compará-los, o ensaísta outra vez privilegia a concepção evolutiva de história literária, conforme a qual a tradição de uma nação, no caso, Portugal, cresce e aperfeiçoa-se ao longo do tempo, para chegar ao apogeu em um dado momento de sua trajetória.

Os demais autores citados pertencem ao século XVIII, como Tibério Pedegache Ivo (1730?-1794), Domingos dos Reis Quita (1728 - 1770) e Pedro Antônio Correia Garção (1724 - 1772?), e ao começo do século XIX, como Vicente Pedro Nolasco da Cunha (1773-18??) e Almeida Garrett, cujos nomes não são mencionados, mas o de suas peças, respectivamente, $O$ triunfo da natureza e Catão. Dentre os dramaturgos do século 
XVIII, Denis lembra a condessa de Vimieiro, Teresa de Melo Breyner (1739-depois de 1798), que concorrera anonimamente ao prêmio da Academia Real de Ciências com a tragédia Ósmia e fora vencedora. Discute a apreciação de Simonde de Sismondi, que considera o texto a melhor tragédia portuguesa do período, ao contrário de Denis, que prefere a Nova Castro, de João Batista Gomes, incluída em sua coletânea.

Também consta da relação o nome de Manuel Caetano Pimenta de Aguiar, cuja peça citada, O rei D. Sebastião, não é escolhida para a antologia francesa. Em seu lugar, Denis prefere $A$ conquista do Peru e Caráter dos lusitanos, títulos, todos, que parecem comprovar a aludida predileção pelos "assuntos nacionais". Embora constitua um de seus eleitos, o ensaísta não deixa de reconhecer que aos diálogos de Pimenta de Aguiar falta "rapidez", ausência de concisão que compromete o andamento da ação.

Na conclusão, o autor da "Notícia" menciona títulos de peças que viu encenadas, obras que talvez não tenham sido publicadas. Refere-se igualmente a um dos gêneros preferidos - o entremez - do público que vai ao teatro em Lisboa e no Rio de Janeiro. As duas indicações sinalizam não apenas a freqüência do ensaísta ao teatro, atividade que atraía grande audiência no século XIX, mas sua familiaridade com os palcos portugueses e brasileiros em virtude de sua passagem por aquelas cidades.

Escrevendo para o público francês, Ferdinand Denis apresenta o teatro português desde uma dupla perspectiva. De um lado, fala o publicista, que deseja valorizar seu produto, mostrando não apenas suas qualidades, mas sobretudo sua importância. Essa reside principalmente na primogenitura - em Portugal, o teatro apareceu antes que na França, e isso basta para ele. Reconhece que, na Itália, as atividades dramáticas tinham sido retomadas antes de Portugal, mas tal precedência não prejudica seu raciocínio. Não menciona a Espanha, talvez por desconhecer La Celestina, de Fernando Rojas (14701541), de 1499; e a dramaturgia inglesa, especialmente a obra de William Shakespeare (1564-1616), ainda não provocara o impacto de que são sintomas os estudos de Stendhal (1783-1842) e Victor Hugo. ${ }^{8}$

Por acreditar que o grande mérito da dramaturgia portuguesa situa-se na precocidade - que menciona ainda nas frases finais de seu estudo, ao lembrar que a nação portuguesa foi "uma das primeiras na poesia dramática" -, examina a obra dos autores do século XVI a cujos textos teve acesso, destacando principalmente Antônio Ferreira e Luís de Camões. A coletânea das obras-primas provavelmente não previa a edição de textos do passado, por isso, Denis elege autores de seu tempo, como José Batista Gomes e Pimenta de Aguiar; mas a ausência de comediógrafos deve ter justificado a inclusão de Antônio José, autor da primeira metade do século XVIII.

De outro lado, fala o historiador da literatura, cuja vocação desabrocha de modo mais completo por ocasião da redação dos Resumos da história literária de Portugal e do Brasil, publicados em 1826 e leitura obrigatória da maioria dos românticos brasileiros de primeira geração, como Joaquim Norberto (1820-1891) e Pereira da Silva (1817-1898). Nesse sentido, nesse curto texto de Denis encontram-se elementos fundamentais para se entender seu posicionamento diante da história literária, que revelam, de uma parte, a incorporação da perspectiva historiográfica que dominará o século XIX, caracterizada 
por: a preocupação com as origens; a identificação das primogenituras; o apoio na cronologia; o crédito conferido à continuidade; a opção pela forma narrativa.

Também significativas da adoção do foco historiográfico do século XIX são o relacionamento com o contexto histórico e a atribuição de causas políticas às principais realizações literárias e artísticas. Assim, o século XVI é período de apogeu da dramaturgia, porque coincide com o poderio econômico e militar de Portugal; no século XVII, há a retração da literatura e a decadência por efeito do que ele classifica de "jugo espanhol". Essa concepção, que entende a história da literatura como subsidiária e reflexo da história de uma nação, tornou-se hegemônica a partir do começo do século XIX, com a consolidação dos Estados nacionais, e manteve-se dominante ao longo do século XX. Ferdinand Denis é um de seus adeptos e usuários, e na época talvez não pudesse ser muito diferente, leitor que ele foi de Simonde de Sismondi. ${ }^{9}$

De outra parte, verificam-se os critérios imprescindíveis para a avaliação das obras. O primeiro, ainda não empregado de modo intenso, como ocorre mais adiante nos Resumos da história literária de Portugal e do Brasil, diz respeito à presença do nacional. Denis lembra o tópico a propósito da tragédia Castro, de Antônio Ferreira, que adota assunto nacional em uma época em que não se esperaria essa escolha. A opção pela língua vernácula diferencia igualmente a obra de Ferreira, aspecto apreciado por Denis.

Mais importante, na "Notícia", é, porém, a relação com os antigos, que Denis examina de modo ambíguo: reconhece, em Ferreira, a validade de sua opção por escrever uma tragédia, elegendo como paradigma a obra de Sófocles. Da mesma maneira, não se opõe à idéia de comediógrafos, como Gil Vicente ou Antônio José, serem comparados a Plauto. Contudo, ao elogiar Ferreira, ele observa que esse autor "soube imitar os antigos com espírito original", atribuindo peso à inventidade, critério relevante nos termos do cânone romântico. Por outro lado, na seqüência do raciocínio, no mesmo parágrafo, Denis se opõe ao que considera uma concepção errônea da história da literatura, segundo a qual "os imitadores dos antigos, no século XVI, colocaram, todos, obstáculos ao progresso do espírito humano".

Denis privilegia igualmente um critério que se poderia considerar de ordem estrutural, além de dizer respeito especificamente ao teatro, gênero com o que lida em seu ensaio. O andamento da ação é, para ele, o fundamento da qualidade de um texto, ao qual os demais se subordinam. Reconhece-se, nessa acepção, o resíduo aristotélico, formulado na Poética e reiterado na Arte poética, de Boileau, pensador que sistematizou as bases da dramaturgia francesa do século XVII, presentes na obra de Corneille (16061684) e, em especial, em Racine (1639-1699), paradigmas do Classicismo imitado por seguidores dentro e fora da França.

Ao privilegiar a ação e ao reconhecer a comédia e a tragédia enquanto gêneros representativos do drama, Denis revela sua formação, calcada nos modelos ainda vigentes do Classicismo. Esses viriam a ser contestados e substituídos pelos românticos, que transformariam o drama histórico em alternativa para a tragédia, ao introduzir nessa os assuntos nacionais que Denis reconhecia em seus contemporâneos, mas cuja designação ainda não fora formulada. O Prefácio a Cromwell, com o qual Victor Hugo revolucionou a dramaturgia do século XIX, não fora ainda redigido, logo, Denis, não poderia pensar de modo muito diferente. 
Ao publicar a "Notícia sobre o teatro português", Denis coloca-se entre dois tempos e duas estéticas: a do Classicismo, ainda vigente, e a do Romantismo, cujos traços não apresentavam consistência suficiente para serem reconhecidos e admirados. Mas o ensaísta não recusa a literatura de seu tempo, procurando, pelo contrário, respeitála e divulgá-la. Lendo o teatro português, na posição de intérprete credenciado por importante casa editorial de Paris, mostra-se indivíduo de seu tempo, cujo conhecimento coloca à disposição de seu público.

$\mathrm{Na}$ França pós-napoleônica do Ancient Régime, Ferdinand Denis estimula os laços de Portugal com a França, que alarga suas fronteiras culturais ao acolher obras-primas do teatro mundial. 


\title{
NOTÍCIA SOBRE O TEATRO PORTUGUÊS ${ }^{10}$
}

\author{
FERDINAND DENIS \\ Tradução: Regina Zilberman ${ }^{11}$
}

Como todas as nações que marcaram a literatura da Europa, Portugal teve alguns poetas antes de possuir um único autor dramático. Sob este belo clima, homens dotados de uma imaginação ardente celebraram o amor, bem antes que se sonhasse interessar os espectadores com a encenação das paixões que aquele fazia nascer. A história literária dos primeiros tempos ensina que, desde $1139,{ }^{12}$ muitos cavaleiros, semelhantes aos trovadores do mediterrâneo da França, começaram a dar forma um pouco menos regular a essa linguagem, que deveria se prestar a exprimir os belos pensamentos dos poetas do século XVI, ainda que essa época ofereceu tão-somente uma reunião extravagante de língua romana, árabe e latim. Com efeito, quando vemos as canções de Egas Moniz, ${ }^{13}$ conservadas por Faria, ${ }^{14}$ e lamentamos com ele as infidelidades da amante que o conduziram ao túmulo, não podemos reconhecer a língua de Camões ${ }^{15} \mathrm{e}$, mesmo, como disse um crítico estimado dos portugueses, nesses primeiros tempos da poesia, a invenção gótica das rimas era quase o único caráter que a distinguia da prosa. Nos séculos XIII e $\mathrm{XIV}$, os monarcas portugueses não desdenhavam cantar acontecimentos que haviam produzido algumas revoluções em seu império ou celebrar uma ciência cujos elementos eram ensinados pelos árabes. D. Dinis, ${ }^{16}$ conhecido por sua coragem e pela energia que demonstrou contra os mouros, compôs poesias conservadas em algumas bibliotecas. ${ }^{17}$ Afonso $\mathrm{V}^{18}$ cantou, diz-se, a perda da Espanha pelos árabes e, a seguir, os efeitos da alquimia; mas a língua que utilizaram estava tão na infância quanto aquela dos nossos autores do século XIV; começa-se, porém, a ver em outras produções dessa época que o gosto da poesia italiana se difundia em Portugal e que Petrarca ${ }^{19}$ foi lido.

Ainda que os primeiros anos do século XV tenham visto eclodir um número bastante grande de poetas, quase nada foi conservado dos mais célebres; e Macias, ${ }^{20}$ apelidado o Enamorado, embora tenha oferecido aos portugueses o gênero que eles adotaram por longo tempo, só deixou como provas de seu talento alguns fragmentos pouco consideráveis. Encarcerado por longo tempo, inspirado por seus males, ele cantou em versos galegos os infortúnios que sofreu. Sua ingenuidade interessa, mas surpreende o fato de vê-lo formar uma escola tão numerosa; ele foi imitado, diz-se, por muitos de seus compatriotas e até pelos espanhóis. Temos a triste certeza de que seus sofrimentos não eram imaginários: um marido em quem ele despertou o ciúme matou-o com um golpe de dardo em 1495, e privou o ocidente da Europa de um homem que poderia ainda avançar sua literatura. Arrebatado por uma viva paixão, tendo, segundo se diz, por objeto a irmã do rei D. Manuel, ${ }^{21}$ Bernardim Ribeiro ${ }^{22}$ começou a cantar seus amores pouco depois sobre o mesmo tom, porém com mais moderação. Suas obras foram impressas. Nota-se sobretudo em suas éclogas verdadeiro talento; logo foi seguido por outros poetas, não ousando criar um novo gênero, ainda que os grandes acontecimentos que agitaram Portugal, e ainda se preparavam, devessem apresentar brilhantes assuntos à sua imaginação. Por 
volta dessa época, a língua, singularmente enriquecida, oferecia alguns bons escritores em prosa entre os historiadores. João de Barros, ${ }^{23}$ Bernardo Brito, ${ }^{24}$ Morais ${ }^{25}$ contribuíam talvez mais que os poetas a formá-la e a deixá-la suscetível de ser empregada pelos grandes homens que viriam a aparecer.

É por volta de 1505 que Portugal começou a gozar das produções de seu primeiro poeta dramático: Gil Vicente ${ }^{26}$ apareceu de repente, sem outro mestre que os antigos, e mereceu o título de Plauto ${ }^{27}$ português. Seu maior mérito foi certamente aparecer em uma época em que as diferentes literaturas nada possuíam do gênero que ele adotara. Sob D. Manuel, no momento em que tinha acabado de encontrar o caminho que conduzia às Índias orientais, a corte de Portugal tomou necessariamente um novo brilho. Os jogos ensinados pelos mouros não podiam mais satisfazer os conquistadores da Ásia, desejavam-se mesmo representações teatrais diferentes desses mistérios que começavam a convir menos ao gosto de uma nação guerreira. Gil Vicente, após ter composto seus autos ${ }^{28}$ sagrados, compreendeu provavelmente a necessidade de divertir os espectadores por meio de peças análogas ao gosto aventureiro deles, e deu-lhes desde então tanto comédias quanto tragicomédias que serviram talvez, na seqüência, de guia aos Quevedo $^{29}$ e aos Lope de Vega. ${ }^{30}$

Seus dramas tiveram um sucesso crescente, e o gosto por eles expandiu-se com uma tal atividade, que D. João III quis desempenhar um papel em um deles, para descansar de suas graves meditações sobre o comércio da Ásia. Ainda que, um pouco mais tarde, as mulheres não fossem admitidas no teatro, e os jovens fossem obrigados a desempenhar o papel delas, essa prática não era tão severa na época de Gil Vicente; sua filha Paula foi vista como a maior atriz de seu tempo e destacou-se por sua habilidade na maioria das artes amenas. $\mathrm{O}$ autor de que nos ocupamos adquiriu logo uma tal reputação, que Erasmo ${ }^{31}$ quis aprender português para se convencer de seu talento; e julgou que ele tinha imitado muito bem a Terêncio. ${ }^{32}$ Segundo a Biblioteca Lusitana, ${ }^{33}$ Gil Vicente não imprimiu suas obras enquanto viveu, mas teve três filhos que publicaram, em 1562, um volume in-folio contendo todas suas peças. Esta coleção foi dividida em cinco livros, compreendendo os autos, as comédias, as tragicomédias, as farsas, e enfim as pantomimas de que Bouterwek ${ }^{34}$ não fala. Infelizmente esta obra tornou-se tão rara, que só dificilmente é encontrável, mesmo em Portugal. O que Bouterwek observou não dá uma idéia muito vantajosa dela; mas os portugueses instruídos asseguram que se encontram, em várias peças, cenas de um verdadeiro talento. Lamento não poder oferecer a meus leitores uma análise deste poeta dramático, que precedeu os da Espanha, da Inglaterra e da França.

Barbosa afirma que um dos filhos de Gil Vicente ultrapassou de tal modo o talento de seu pai, que, para não diminuir a glória desse, foi enviado à Índia, onde morreu. ${ }^{35}$ Não se esclarece se foi sua família que exerceu este ato arbitrário ou o governo de D. João III; parece apenas que este segundo Vicente compôs um grande número de autos sacramentais e profanos, entre os quais se estimou sobretudo D. Luiz de los Turcos. ${ }^{36}$

O concurso de circunstâncias que dava impulso tão extraordinário a Portugal, e fazia nascer entre seus habitantes o desejo de elevar-se ao auge da glória, desenvolveu repentinamente entre alguns homens privilegiados um gênio desconhecido pelas outras 
nações. Vimos aparecer quase à mesma época Sá de Miranda, ${ }^{37}$ tão conhecido por suas encantadoras elegias; Ferreira, ${ }^{38}$ que lembra seguidamente Horácio ${ }^{39}$ em suas epístolas; Pero de Andrade Caminha, ${ }^{40}$ bem sucedido em vários gêneros de poesia; Diogo Bernardes,${ }^{41}$ célebre pela sua analogia no estilo com o primeiro dos autores portugueses; Jerônimo Corte-Real, ${ }^{42}$ tão tocante em sua narrativa dos insucessos de Sepúlveda; Rodrigues Lobo, ${ }^{43}$ o mais arrebatador dos poetas bucólicos, e vários outros autores, que parecem terem-se reunido para fixar a linguagem. Camões era também contemporâneo da maioria deles; mas, lançado em uma vida agitada, continuamente distante da pátria, preparava em segredo o monumento de sua glória e não gozou, como os que nomeamos, a felicidade de ser apreciado por seus compatriotas.

Ainda que alguns homens se entregassem especialmente ao teatro à época de que falo, os autores célebres que ilustraram os reinos de D. Manuel, D. João III e D. Sebastião, ${ }^{44}$ pareciam ocupar-se dele apenas acidentalmente e acompanharam mais os passos dos antigos que seu predecessor Gil Vicente.

Sá de Miranda, que esteve na Itália, introduziu provavelmente em sua pátria, o gosto pelas peças imitadas dos cômicos latinos que se começavam a apresentar na corte de Leão X. ${ }^{45}$ Aquele autor, visto como o primeiro que fez grandes versos em português, dominava perfeitamente várias línguas, e entregou-se sobretudo ao estudo do grego. $\mathrm{Na}$ seqüência de uma viva altercação com um grande senhor, foi obrigado a isolar-se, quando se entregou mais do que nunca à cultura das letras. Aproveitou as observações que pôde fazer da corte, e percebe-se que ele esteve longe de lamentá-la, apesar das vantagens que pôde lá gozar. Seu caráter é tão estimável quanto seu talento, de que encontramos provas freqüentes em suas obras, em que ele parece ter prazer em pintar-se: "Homem dum só parecer,/ dum só rosto e d'ua fé,/ d'antes quebrar que volver,/ outra cousa pode ser,/ mas de corte homem não é", ${ }^{46}$ escreve ele. Foi, entretanto, para essa corte, que ele desejava instruir, que compôs duas comédias; e o padre Macedo, ${ }^{47}$ em seu elogio latino, parece indicar que elas foram lá representadas. Os Vilhalpandos e Estrangeiros apareceram quase ao mesmo tempo e gozaram de grande sucesso, porque lembravam a excelente comicidade dos latinos a uma época em que tudo parecia novo.

Ainda que Antônio das Neves Pereira ache que aquele autor realiza perfeitamente suas imitações, só concordo com ele no que se refere ao estilo. ${ }^{48} \mathrm{Em}$ Os Vilhalpandos, em que há algumas cenas bastante agradáveis, buscamos em vão uma ação: ela é anunciada continuamente e não acontece. Estrangeiros apresentam talvez um pouco mais de interesse, mas temos o direito de acusá-la do mesmo defeito da peça precedente.

Ainda pela metade do século XVI apareceram quatro autores que se dedicaram ao teatro e obtiveram uma espécie de celebridade, não mencionados, porém, nas obras estrangeiras que falam da literatura de Portugal. Parecem pertencer à escola de Gil Vicente e compuseram principalmente autos: parece que este gênero de peça, conservando um título quase religioso, não adotava em princípio necessariamente assuntos sagrados.

Antônio Prestes, ${ }^{49}$ o cômico mais fecundo de todos os que falo agora, compunha com muita rapidez, igualada mais tarde só por Lope de Vega. Durante sua vida, publicou comédias e diferentes autos, reunidos após sua morte, provavelmente com outras peças, por Antônio Lopes ${ }^{50}$ funcionário da Capela Real. São encontráveis na Primeira parte dos autos e comédias portuguesas, publicada em Lisboa em 1587, por André Lobato. 
Sebastião Pires, ${ }^{51}$ empregado pelo deão de Faial, em 1556, foi verdadeiro gênio da poesia dramática. Parece que sua principal obra intitulou-se Representação dos gloriosos feitos extraidos do texto sagrado. A nau do filho de Deus foi impresso com uma écloga, intitulada Silvério, em 1577.

Antônio Ribeiro, ${ }^{52}$ embora tendo recebido pouca instrução, conseguiu alcançar noções de belas letras; improvisou, diz-se, com facilidade e imitava tão bem, segundo Barbosa, os gestos e o acento das diferentes personagens que se poderia vê-las ou ouvilas. Deixou várias comédias, mas seu Auto da natural invenção foi representado perante D. João III. Morreu em 1591.

Simão Machado, ${ }^{53}$ que parece ter estado na Índia, compôs a comédia do Diu e a da Pastora Alfea; não se sabe o sucesso que obtiveram.

Jorge Ferreira, ${ }^{54}$ autor de um romance da Távola Redonda, escreveu em prosa Eufrósina, Ulisipo, a Aulegrafia; as três comédias gozam ainda de grande estima, sobretudo por causa do estilo. Infelizmente só encontramos essas peças nas antigas bibliotecas de Portugal; parece que as coletâneas que as reúnem foram, na maioria, destruídas quando do terremoto em 1755. Seriam monumentos úteis para a consulta, mais para observar a trajetória da poesia dramática, que para extrair delas assuntos interessantes ou idéias engenhosas.

Até aqui não havia aparecido uma única tragédia digna deste nome, exceto na Itália; quando Antônio Ferreira, que não parece ser parente do que já citei, seguiu essa carreira após ter produzido duas comédias, quis experimentar um gênero mais elevado e deu desde então provas irrecusáveis de verdadeiro gênio. $\mathrm{O}$ autor, sempre movido pelo amor à pátria, e bem distante dos passos de seus contemporâneos, que pareciam freqüentemente desdenhar sua língua, para escrever em latim ou em espanhol, quis provavelmente mostrar que ela era suscetível de expressar os pensamentos mais nobres; mas ele transpôs ao mesmo tempo as regras muito austeras da rima. O fim terrível de Inês, cuja lembrança ainda ocupava os espíritos depois de mais de dois séculos, pareceu-lhe dever excitar a compaixão de um povo que a lastimava há muito tempo: havia ao menos a ousadia ao adotar este assunto nacional, pois ele desejava abordá-lo por volta de 1557, segundo as formas simples dos trágicos gregos, em uma época em que o gosto da nação parecia em desacordo com o gênero que adotaria. ${ }^{55}$ Não podemos esconder que foi preciso, nesta época, um espírito muito justo e muita coragem para escrever com a simplicidade de Sófocles ${ }^{56}$ sua tragédia, quando era provável que ela produziria mais efeito sobre os contemporâneos, conformando-se às regras do período. Como bem disse um autor português: se não restar outro monumento do talento deste poeta, isso bastaria para provar que ele soube imitar os antigos com espírito original e que ele não pode ser compreendido nessa proposição tão absoluta quanto falsa, pela qual muitos modernos alteram a história literária, dizendo que os imitadores dos antigos, no século XVI, colocaram, todos, obstáculos ao progresso do espírito humano. O maior defeito da peça de Ferreira recai inteiramente sobre a ação, pois os caracteres estão bem desenhados, e as situações são, na maioria das vezes, interessantes. O estilo apresenta belezas de primeira ordem, mas é sobretudo nas partes corais que Ferreira mostra como foi inspirado pelos antigos. Seguidamente, mesmo Horácio, que ele imitou em outras poesias, fornece-lhe a cena de pensamentos sublimes. 
Ainda que as duas comédias deixadas pelo mesmo autor estejam longe de estar desprovidas de todo mérito, elas não podem, porém, marcar a época na literatura como a tragédia que mencionei. Entretanto, em uma dessas produções, vemos de novo Ferreira animado pelo desejo de ser útil, já que ele não se contenta em divertir o espírito de seus espectadores pela intriga, mas concebe desde então a boa comédia, pintando um caráter. O cioso não está, infelizmente, bem concebido; mistura aventuras extravagantes, algumas, porém, engenhosas e capazes de dar destaque à personagem; contudo, é impossível deixar de reconhecer aí alguns bons gracejos, freqüentemente retirados dos cômicos latinos.

Como $O$ cioso pode ser considerada uma das primeiras peças de caracteres quando do renascimento no teatro na Europa, se não for mesmo a mais antiga deste gênero, creio dever analisá-la.

A cena se passa em Veneza: o ciumento, de nome Júlio, desposou Lívia, filha de um rico particular, e tornou-a a mais infeliz das mulheres, dadas as extravagâncias de sua personalidade. Bernardo, jovem português, que a amou há mais tempo, chega de Lisboa e confessa seus sentimentos ao amigo de infância Otávio; é ao ciumento que ele dirigiu cartas de recomendação; mas seu pajem, que chegou antes, foi tão mal recebido, que ele não julga conveniente apresentar-se. Ao mesmo tempo, esse pajem introduziu-se na casa; ele conta os maus tratos que Lívia experimenta e o vivo desejo que ela tem de receber o homem que a amou tão profundamente. Os dois amigos descobrem que Júlio deseja obter os favores de uma jovem cortesã chamada Faustina, amante de Otávio, e eles imaginam, para se desembaraçar do ciumento, um meio que não mais se admitiria em nosso teatro: o fiel amigo de Bernardo pede à sua amante que se encontre com Júlio durante a noite; mas ela se irrita com tal proposta, tomando a resolução de um dia vingarse. Júlio, por seu turno, que lhe oferecerá um anel, quer ver o efeito que causará; como deve passar a noite fora, previne a governante Brômia que não abra a quem quer que seja e, para evitar qualquer trapaça, que não deixe nem ele entrar, quando se identificar. Brômia não tarda a instruir o pajem desta circunstância, e Bernardo logo se acha dentro da casa. Júlio chega à casa de Faustina, mas perde o anel, é expulso de lá e não pode nem ser recebido na sua, de modo que se vê obrigado a pedir asilo ao sogro, vivamente irritado com ele há longo tempo. Enquanto isso, Bernardo reaparece em cena; informa-nos que a virtude de Lívia iguala suas demais qualidades e que não poderá deixar de vingá-la, se continuar a ser vítima de maus tratos. Sua resolução é inútil, pois o ciumento fez reflexões muito rápidas, mas muito felizes para os que o rodeiam; a noite mudou-o muito, ele toma a firme decisão de corrigir-se de seus defeitos, de tornar-se um bom marido, e mesmo de receber o hóspede chegado de Portugal. Acontece que, por um incidente totalmente alheio à peça, Bernardo e Otávio são dois irmãos; eles devem retornar logo a Lisboa.

É sobretudo no desenlace que vemos a infância da arte, pois a peça é, em geral, bem escrita e apresenta caracteres traçados com felicidade; não podemos dissimular, porém, que há personagens totalmente inúteis e que só servem para travar a ação.

No que se relaciona à imitação dos antigos, é fácil dar grande número de exemplos do que indiquei; contentar-me-ei em citar a cena III do primeiro ato, que considero 
a mais cômica na peça e cujos melhores gracejos foram literalmente tomados de Terêncio, como já observou um crítico português:

Julio - Lembrou-me agora que se me escusou aquela senhora com a visitação de sua mãe, digo que não quero, que pai, nem mãe, nem irmão, nem parente, nem vizinho, nem amigo, nem amiga, nem compadre, nem comadre, nem rei, nem rainha, nem que venham do paraíso, entrem nessa casa.

Brômia - Se nesta casa for necessário fogo, ou água, ou outra coisa, ou a vierem pedir de fora, não queres?

Júlio - Não, digo que não quero esse fogo, e se em casa o houver, mata-o logo, porque não aja razão de o virem buscar. A água digam que fugiu, pineira, joeira, gral, caldeira, e tudo o mais, que as importunas vizinhas soem pedir, diz-lhe que o não há aqui e que vieram os ladrões e que o levaram.

Brômia - E quem me crerá isso?

Júlio - Se to não crerem, que se enforquem, que não quero que em minha casa entre ninguém, sendo eu fora. ${ }^{57}$

Não estenderei a citação; será suficiente indicar a passagem do cômico latino para que todos a reconheçam, e lembraremos oportunamente, cave quemquam alienum in aedis intro miseris, etc. ${ }^{58}$

Lamento que os limites da notícia não me permitam citar a continuação da cena e o monólogo do ciumento; reconhecer-se-ia aí um gênio mais original e um homem que entrevia, como já observado, os recursos da verdadeira comédia.

Não me referirei muito a Bristo; esta peça precedeu, em muitos anos, a que acabo de analisar. Ferreira a compôs com 26 anos, e ela foi bem acolhida pela Universidade de Coimbra, em 1554; é certamente inferior a $O$ cioso. A principal personagem, cujo vergonhoso emprego impede sua aceitação em nosso teatro, impossibilitou a tradução, ainda que o estilo não seja em geral inconveniente.

Surpreende que, a uma época em que o gênero pastoril parecia tocar a nação e em que pastores, em seus diálogos, empregavam apenas expressões bastante melancólicas, os dramas não assimilassem com freqüência o gosto para os sentimentos romanescos. Entretanto, vemos alguns autos em que a dor é expressa ao lado de gracejos mais triviais.

O primeiro poeta de Portugal que se destacou em quase todos os gêneros, conhecido na França apenas por Os Lusíadas, o imortal Camões, desejou tentar a comédia; mas, neste gênero, ficou abaixo de seu talento, e Filodemo, Seleuco e Anfitriões nada acrescentam à sua glória. Estas peças, contudo, ainda que imperfeitas, provam que os maiores homens de Portugal viam, como os italianos, a necessidade de criar um teatro antes que os autores pertencentes a outras nações se ocupassem seriamente dele.

Como Camões sempre se sentia disposto a celebrar as paixões vivas, ele escolheu um assunto que podia tratar melhor que os outros, e Antíoco morrendo de amor por Estratônica, esposa de seu pai, Seleuco, pareceu-lhe digno de ser posto em cena. ${ }^{59}$ Ele seguiu as regras adotadas pelos autores de autos, e não sabemos que título seria preciso dar em nossos dias à peça que designa sob o nome de comédia. Ainda que escrita em versos, é precedida por um prólogo em prosa, em que o Escudeiro conclama os especta- 
dores a fruir o espetáculo que se prepara; um moço interrogado por alguns interlocutores diz alguns gracejos desagradáveis que hoje não toleraríamos e que não têm nenhuma relação com a peça. Entretanto, parece que, no discurso feito ao final pelo Representador, o poeta tem a intenção de criticar a desordem que reinava em muitos autos; e é preciso convir que o andamento da peça é extremamente simples. Esta pequena comédia não se divide em atos ou em cenas; anuncia-se que tal personagem entra e fala, sem que o jogo de atores seja indicado.

Estratônica entra em cena inicialmente com o rei e noticia-lhe a doença do príncipe. Esse chega em seguida, acompanhado por seu pajem Leocádio; ele parece, durante um diálogo bastante longo, não perceber as outras duas personagens, para ter tempo de confessar ao confidente o tormento por que passa. Ele decide-se enfim a aproximar-se do rei, que o induz a deixar-se visitar por um médico e prepara-lhe um leito, a fim de que repouse com mais tranqüilidade. Eles se afastam por um momento e são substituídos por uma serva, que tem uma cena muito singular com um porteiro, e adverte-o, após escutar algum tempo, que o príncipe vai se deitar. Antíoco chega, testemunha o desejo de ouvir música, mas acaba por adormecer; a rainha, entrando, lamenta o estado a que ele se reduziu; quando sua confidente entrega-lhe um papel que ele acabou de jogar no chão, mostra-se a paixão que o devora. É então que Estratônica revela a sua; ela quer unir-se com o príncipe após sua morte, se não puder fazê-lo durante sua existência. Assim que ela parte, chega o médico, que mede o pulso do doente; ele chama um servo que tem o nome português de Sancho, pedindo-lhe que busque Seleuco. O rei não tarda a chegar, seguido imediatamente por Estratônica. Após algumas perguntas feitas ao príncipe, o médico não tem mais dúvidas quanto a seu mal, tomando a resolução de usar de artifícios para obter para ele a mão da rainha. Eis como ele se explica, depois de todos saírem:

\section{Rei \\ Porquê? \\ Físico:}

Porque tengo entendido

lo más malo de entender, para lo que puede ser, porque anda, Señor, perdido

d'amores por mi mujer.

\section{Rei}

Santo Deus! Quê! Tal amor

lhe dá doença tão fera?

Que remédio achais milhor?

Físico:

Forzado será que muera, porque no muera mi honor.

Rei

Pois como! A um só herdeiro deste reino não dareis 
vossa mulher, pois podeis, que tudo faz o dinheiro? Pois este não o enjeiteis; dai-lha, porque eu espero

de vos dar dinheiro e honra, quanto eu para ele quero.

Físico:

No tira el mucho dinero la mancha de la deshonra.

Rei

Ora bem pouco defeito!

É pequice conhecida, quando deixa de ser feito, porque com ele dais vida a quem vos dará proveito.

Físico:

¡Cuán facilmente aporfia quién en tal nunca se vió! ¿Del consejo que me dió, vuestra Alteza que haria si ahora fuese yo?

Rei

A mulher que eu tivesse dar-lha ia. Oxalá que ele a Rainha quisesse!

Físico:

Pues dela, si le parece, que por ella muerto está.

Rei

Que me dizeis?

Físico:

La verdad.

Rei

Sem duvida, tal sentistes?

Físico:

Sin duda, sin falsedad.

Pues, Señor, ahora tomad

los consejos que me distes.

Rei

Certamente que eu o via em tudo quanto falava.

Como o vistes? Porque via?

Físico: 
Nel pulso, que se alteraba si la vía, o si la oía.

Rei

Que maneira há de haver?

Que eu, certo, me maravilho,

possa mais o amor de filho,

do que pode o da mulher.

Finalmente, hei-lha de dar, que a ambos conheço o centro.

Quero-o ir levantar,

e iremos pera dentro

neste caso praticar. ${ }^{60}$

Com efeito, ele faz seu filho levantar, e o resto da cena se passa entre o porteiro e o pajem. Mas vemos logo reaparecerem as duas principais personagens, que se uniram, e a peça termina por um pequeno discurso burlesco em gênero semelhante ao do prólogo.

Acreditei dever oferecer a análise dessa peça, primeiro por causa da reputação de seu autor, depois porque ela dá uma idéia dos autos deste gênero. O andamento de Seleuco apresenta, como se vê, um tipo de regularidade; mas o assunto comporta outro estilo, e é difícil imaginar como o admirável Camões não tirou partido de situações que se achavam indicadas, para expor o encanto que se encontra em suas poesias. Por uma extravagância digna de reparo, o médico fala sempre em espanhol. Pode-se observar também que essa língua é utilizada em Anfitriões, que não analisarei, porque imita Plauto. As situações comportavam estilo mais agradável que o da peça precedente; mas o do poeta português serve para provar ainda em que grau nosso Molière ${ }^{61}$ se elevou, imitando o autor latino.

Filodemo, ainda que mais considerável que as outras duas comédias, não parece ter sido originalmente dividida em muitos atos; as unidades de tempo e de espaço não são mais observadas que as leis da verossimilhança; e bastará apresentar uma rápida análise da peça, para que nos convençamos disso. O herói faz parte dos servidores de uma personagem poderosa, denominada Lusidardo, cuja filha, Dionisa, ele ama e, sem saber, é retribuído; ele logo descobre isso, quando a servente lhe relata a agitação de sua ama e o prazer que ela experimenta ao ouvi-lo cantar suas queixas, acompanhado pela guitarra. Ele manda-lhe um bilhete em que manifesta sua paixão, e vemos que Dionisa está longe de se irritar. Enquanto isso, outra ação se prepara; o filho de Lusidardo, Venadoro, se perde, caçando um cervo nas montanhas; em vão, seus companheiros procuram reencontrá-lo. Repousando perto de uma fonte, encontra uma jovem buscando água; ele a admira, fala-lhe, sente-se logo tomado por um amor tão violento, que decide cuidar de um rebanho, para viver sempre perto dela. Entretanto, Lusidardo, inquieto por causa de seu filho, deixa Filodemo encarregado de sua casa e parte para buscá-lo no lugar em que desapareceu sob os olhos dos acompanhantes. O velho erra por longo tempo nas montanhas, quando percebe um matrimônio na vila: é seu filho que desposa a pastora Florimena. Um velho pastor informa-lhe que encontrou, há algum tempo, essa moça e um menino, 
junto à sua mãe que morria e que, graças à arte da magia, que era sua profissão, descobriu que esta mulher infeliz era uma grande princesa. Ele se oferece para informá-lo mais a respeito do assunto e diz que o rapaz, desejando elevar-se acima do estado que poderia lhe oferecer, mudou-se para a corte. Lusidardo fica contente com a aliança; ele leva todos consigo, quando descobre que Florimena é irmã de Filodemo, sendo que Lusidardo reconhece neles os filhos de seu próprio irmão. Esse, enviado há muito tempo a Dinamarca, teve um caso com a filha do rei e viu-se obrigado a fugir com a esposa em um navio que partia para Portugal; mas, quando chegavam à costa, uma tempestade os apanhou, o barco bateu nos rochedos, a tripulação pereceu, exceto a princesa, que se viu empurrada pelas ondas até as margens. Após vagar muito tempo no deserto, as dores do parto a tomaram de surpresa, e ela deu luz, pouco antes de morrer, às duas crianças encontradas pelo pastor. Após ser informado desses maravilhosos acontecimentos, Lusidardo não recusa sua filha a Filodemo; com muito mais razão, ele os surpreende juntos quando retorna. A peça termina por uma dupla união.

Há, nesta comédia, muitos atores que não nomeei e cujos gracejos são de muito mau gosto. Vilardo, criado da personagem principal, Bobo, filho do velho pastor, são tipos de graciosos que não concorrem para o andamento da peça. $\mathrm{O}$ estilo mais harmonioso, e sobretudo mais poético que o das outras duas comédias, oferece uma singularidade notável; nem todas as cenas são versificadas, e algumas são inteiramente escritas em prosa, sem que o autor pareça ter tido, para agir assim, motivos que se relacionassem a esse gênero de composição. Apesar dessas extravagâncias, encontramos em Filodemo algumas cenas agradáveis; e talvez o gênio de Camões mostre-se aí mais que em Selenco e em Anfitriōes.

As catástrofes ocorridas à época do rei D. Sebastião, e as longas infelicidades que se seguiram a elas, tiveram tal influência sobre a literatura portuguesa, que ela pareceu entrar em decadência com a glória da nação. Algum tempo depois, quando o jugo espanhol se fez sentir, os portugueses lembravam-se muito bem de seu antigo poderio, para não procurar reconquistá-lo; mas seus esforços foram, por muito tempo, supérfluos, e o gênio permaneceu adormecido enquanto durou a dominação estrangeira.

Lisboa estava longe de oferecer, por essa época, o aspecto que apresentara sob D. João III; não se viam mais chegarem de todas as partes as riquezas da Índia e da África; estes espetáculos criados pelo luxo, e destinados a descansar os conquistadores de seus trabalhos, deixaram de agradar a um povo ao qual lembravam o período de sua prosperidade. Ao mesmo tempo, outras nações fizeram progressos verdadeiramente prodigiosos na literatura dramática, e Portugal, após ter contribuído para impulsioná-la, ficou para trás, provavelmente por causa das circunstâncias políticas em que se encontrava.

Em 1640, quando da aclamação de D. João IV, ${ }^{62}$ a nação dispunha apenas das antigas peças para opor às obras-primas que a Europa via aparecer diariamente. Entretanto, muitos homens de grande talento quiseram, um pouco mais tarde, regenerar sua literatura dramática. Entre esses, não sei se não podemos citar o célebre padre Macedo, que representou, ante Luís XIV, ${ }^{63}$ Orfeu, tragicomédia latina, e deixou três outras peças do mesmo gênero. Fernando de Meneses, ${ }^{64}$ autor de vários poemas, deixou algumas comédias cujo título foi perdido. Seu neto, o famoso Conde de Ericeira, ${ }^{65}$ um dos autores 
mais fecundos de Portugal, não se ocupou desse gênero; mas tornou-se, ao final de sua carreira, o protetor do infeliz Antônio José, ${ }^{66}$ cujas peças fizeram o povo de Lisboa acorrer ao teatro do Bairro Alto e que deixou um conjunto considerável sem nome de autor, designado às vezes pelo título de teatro do Judeu, mas portando o de Teatro cômico português. Antônio José parece não ter desejado ater-se a alguma regra do teatro, e não imitou mesmo os bons autores do período. Levado por sua verve e por sua alegria, ele às vezes coloca toda a vida de um homem em cena, sem se ocupar muito de atá-la pela intriga; mas a maioria das personagens é agradável, e elas seriam-no ainda mais, se caíssem menos freqüentemente no vulgar. Bem dirigido, foi digno do apelido de Plauto português, que algumas pessoas the atribuíram, assim como a Gil Vicente, ainda que a época em que viveu não pudesse desculpá-lo de suas irregularidades como as de seu predecessor. Este autor foi vítima do auto-de-fé de 1740.

Muito anos depois, por volta de 1761, dois poetas reúnem-se para apresentar tragédias regulares em Portugal. Tibério Pedegache ${ }^{67}$ e Domingos dos Reis Quita, ${ }^{68}$ conhecido por seus idílios, compuseram Astarto, Mégara, Hermíne e uma Inês de Castro em três atos; a segunda dessas peças é a mais estimada, e ela é digna, sob qualquer ângulo, de chamar a atenção. Os autores escolheram o momento em que Mégara, filha de Creonte e esposa de Hércules, é perseguida por Licos, usurpador do trono de seu pai. Alcides retorna dos infernos; descobre que o tirano quer forçar a filha do antigo rei a desposá-lo, ameaçando-a com a morte; busca o socorro de Teseu, e ele faz a reparação no momento em que, Licos ordenando-lhe que Mégara seja levada ao sacrifício, ela o derruba com o punho aos pés do altar de Júpiter. O maior defeito dessa peça, em que se observa, contudo, as belezas do estilo, é ter transformado Hércules em personagem insignificante, fazendo-o buscar ajuda no momento que sua coragem é necessária.

Há algum tempo não nos ocupamos do teatro cômico, enquanto Pedro Antônio Correia Garção, ${ }^{69}$ conhecido pela beleza de suas odes, escreveu duas comédias: uma, intitulada Teatro novo, não obteve grande sucesso; mas a segunda, conhecida sob o título de Assembléia, tem todos os méritos: nota-se aí uma sátira engenhosa à alta sociedade; e os amantes da bela poesia não deixam de admirar a notável cantata que o autor soube aí introduzir. $^{70}$

Começava-se, antes da época a que chegamos, a traduzir em versos portugueses nossas belas tragédias, e nossos poetas dramáticos foram tão apreciados em Lisboa, que se tornaram provavelmente um obstáculo para que os autores nacionais dessem vazão a seu gênio original. A academia percebeu tão bem este vazio na literatura portuguesa, que propôs um prêmio para a melhor tragédia que se apresentasse no mês de maio de 1788. A condessa de Vimieiro ${ }^{71}$ concorreu sem que ninguém soubesse, e a peça intitulada Osmia foi vencedora. Ainda que Simonde de Sismondi, ${ }^{72}$ em sua obra estimável, veja-a como a melhor tragédia portuguesa, nem todos os letrados da nação pensam assim. Esse título é universalmente conferido à Nova Castro, de João Batista Gomes, ${ }^{73}$ que pode ser considerada uma obra-prima e que já alcançou quatro edições. Vemos muitas tragédias modernas perto da mesma época, que gozam da estima do público. O triunfo da natureza ${ }^{74} \mathrm{O}$ rei D. Sebastião ${ }^{75}$ Catãa $^{76}$ foram compostas por homens de talento. O gênio do drama apossou-se de muitos autores, há alguns anos, eu os vi encenados com verdadeiro prazer. 
Pedro I, Frederico visitando as prisões, $O$ serralheiro holandês, $A$ sensibilidade no crime oferecem seguidamente muito interesse e são recentes. ${ }^{77}$

Encenam-se ainda nos teatros de Lisboa, bem como nos do Rio de Janeiro, farsas conhecidas sob o nome de entremez; elas parecem ter substituído os antigos autos e lembram inteiramente seus gracejos. ${ }^{78}$ Lamento não poder analisar outros cômicos; mas, entre todos os livros estrangeiros, as obras portuguesas são talvez as mais raras em Paris; é impossível imaginar, ao menos se a pessoa fez similar pesquisa, as dificuldades por que se passa a procurar algumas peças de teatro pouco difundidas, até em Lisboa.

Entre todos os autores que se ocupam com a regeneração do teatro de sua nação, há um que faz alimentar as mais belas esperanças, Pimenta de Aguiar é autor de um grande número de peças, que deseja reunir sob o título de Teatro trágico português. Agradao principalmente tratar de assuntos nacionais, e ele mostra em geral um talento enérgico; poderíamos apenas desejar mais rapidez nos diálogos, cuja falta de concisão em geral prejudica a ação.

Eis o que minhas pesquisas puderam me ensinar sobre o estado do teatro português antigo e moderno. A nação, uma das primeiras na poesia dramática, começa a sentir seu gênio despertar para este gênero de literatura. A França oferece-lhe há muito tempo suas obras-primas; entretanto, os autores que citei provam que, sabendo tomar partido delas, conferiram às suas produções um caráter original.

Notas

${ }^{1}$ Cf. LE GENTIL, Georges. "Ferdinand Denis, iniciador dos estudos portugueses e brasileiros." Biblos. Coimbra, n. 4, p. 293-323. 1928. p. 293.

${ }^{2}$ Cf. CABRAL, Alfredo do Vale. Anais da Imprensa Nacional do Rio de Janeiro de 1808 a 1822. Rio de Janeiro: Tipografia Nacional, 1881.

${ }^{3}$ Relativamente à permanência de Ferdinand Denis no Brasil, em especial na Bahia, cf. BOURDON, Léon. "Lettres familieres et fragments du journal intime. Mes sottises quotidiennes de Ferdinand Denis à Bahia (18161819).” Brasilia. Coimbra, n. X, p. 143-286. 1958.

${ }^{4}$ Cf. ZILBERMAN, Regina. "As lições de Ferdinand Denis." Gragoatá. Revista do Programa de Pós-Graduação em Letras. Niterói, v. 20, p. 199-218.

${ }^{5}$ Cf. MACHADO, Diogo Barbosa. Bibliotheca Lusitana. Biblioteca Virtual dos Descobrimentos Portugueses. V. 2, p. 384.

${ }^{6}$ As citações são retiradas de: DENIS, Ferdinand. "Notice sur le théatre portugais." In: Chefs d'œuvre du théatre portugais. [Paris]: Ladvocat, 1823. p. 3-28. Tradução nossa.

${ }^{7} \mathrm{Na}$ mesma direção, observa Almeida Garrett: "Eis aí o faceto Antônio José, a quem muitos quiseram apelidar Plauto português e que sem dúvida alguns serviços tem a esse título, porém não tantos como apaixonadamente lhe decretaram. Em seus informes dramas algumas cenas há verdadeiramente cômicas, alguns ditos de suma graça; porém essa degenera a miúdo em baixa e vulgar." In: Garrett, Almeida. "Bosquejo da história da poesia e língua portuguesa.” In: Parnaso lusitano. Paris: J. P. Aillaud, 1826. V. 1.

${ }^{8}$ Racine e Shakespeare, de Stendhal, foi publicado em 1823 e discutido a partir da segunda edição, de 1825; o ensaio de Victor Hugo sobre William Shakespeare data de 1864.

9 Sobre as relações entre as concepções de história e de história da arte, cf. JAUSS, Hans Robert. "Histoire et histoire de l'art.” In: __ _. Pour une esthétique de la réception. Paris: Gallimard, 1978.

${ }^{10}$ Texto publicado originalmente em: Chefs d'œuvre du théatre portugais. Tradução e apresentação de Ferdinand Denis. [Paris]: Ladvocat, 1823. p. 3-28. Coleção Chefs-d'oeuvres des théâtres étrangers. A coletânea organizada por Ferdinand Denis contém: Nova Castro, de João Batista Gomes; A conquista do Peru, tragédia, e Caráter dos 
lusitanos, tragédia, de Manuel Caetano Pimenta de Aguiar; Vida do grande D. Quixote de la Mancha e do gordo Sancho Pança, de António José da Silva. [RZ]

${ }^{11}$ Para a tradução, utilizou-se o texto original, conforme referência colocada na nota de abertura. A obra integral, incluindo a "Notícia sobre o teatro português", pode ser localizada atualmente no endereço http:// books.google.com.br/books. Acrescentaram-se notas de rodapé explicativas, identificadas, ao final,pelas iniciais RZ, colocadas entre colchetes.

${ }^{12} \mathrm{Em} 1^{\circ}$ de novembro de 1139, D. Afonso Henriques (1094-1108) foi coroado rei de Portugal, separando da Espanha o território situado entre os rios Minho e Douro. [RZ]

${ }^{13}$ Egas Moniz (?-1146) foi mordomo-mor e responsável pela educação de D. Afonso Henriques. A João Soares Coelho, o Trovador, descendente por bastardia de Egas Moniz, é atribuída a lenda sobre seu antepassado: Egas Moniz teria oferecido a própria vida, a da esposa e dos filhos, ao rei de Leão, Afonso VII, como maneira de provar que era homem de palavra.[RZ]

${ }^{14}$ Manuel de Faria e Sousa (1590-1649), que se notabilizou por seus comentários a Os Lusíadas, escreveu, em espanhol, a Epitome de las historias portuguesas, distribuído, nas edições póstumas, em três partes: Europa Portuguesa, Ásia Portuguesa e África Portuguesa. Integra a Epitome um inventário de autores, intitulado "De los escritores portugueses", que, ao lado de seu "Catálogo de los escritores portugueses", com 823 entradas, constituiu organização pioneira da tradição literária de Portugal. [RZ]

${ }^{15}$ Luís de Camões (1524?-1580), autor de Os Lusíadas, de 1572, principal epopéia em língua portuguesa, celebra a expansão portuguesa, sintetizada na viagem de Vasco da Gama, contornando a África e chegando à Índia, em 1498. [RZ]

${ }^{16}$ D. Dinis (1261 - 1325), rei de Portugal e poeta, escreveu cantigas de amor, cantigas de amigo e cantigas de maldizer. [RZ]

${ }^{17}$ Faria diz que este rei fez de Coimbra uma nova Atenas e que ele reuniu ali os homens mais ilustres em todos os gêneros, fazendo-os vir às suas custas de seus países de origem. Encontramos um manuscrito de suas obras poéticas em Roma, sob o reino de D. João III, e há um na Torre do Tombo, em Lisboa. É provável que eles tenham-se multiplicado desde então. [D. João III (1502-1557), sucessor de D. Manuel, governou Portugal entre 1521 e 1557. RZ]

${ }^{18} \mathrm{D}$. Afonso V (1432-1481) assumiu o trono de Portugal em 1438. [RZ]

${ }^{19}$ Francesco Petrarca (1304 - 1374) foi um dos principais expoentes do Humanismo renascentista. [RZ]

${ }^{20}$ Data do século XV a lenda dos amores do trovador Macias, que morreu em Jaen, entre 1467 e 1484 . A serviço de Henrique de Aragão, marquês de Vilhena, apaixonou-se por D. Elvira, com quem não pôde casar, mas a quem dedicou canções de amor. Denunciado, foi preso; no cárcere, teria sido assassinado pelo marido enciumado. [RZ]

${ }^{21}$ D. Manuel I (1469 - 1521) governou Portugal durante o período das descobertas, quando Vasco da Gama percorreu o caminho marítimo para as Índias. [RZ]

${ }^{22}$ Bernardim Ribeiro (1482? - 1552?) escreveu a novela sentimental Menina e mosa, provavelmente de 1554, marco da narrativa em língua portuguesa. [RZ]

${ }^{23}$ João de Barros (1496-c. 1570), historiador, pedagogo e ensaísta à época do Renascimento, escreveu as Décadas, em que narra a expansão portuguesa. [RZ]

${ }^{24} \mathrm{O}$ frei Bernardo de Brito (1569-1617), monge da Ordem de Cister, foi historiador, tendo escrito o Elogio dos Reis de Portugal, em 1603. [RZ]

${ }^{25}$ Francisco de Morais (c. 1500-1572) é autor da novela de cavalaria Palmeirim de Inglaterra. [RZ]

${ }^{26}$ Gil Vicente (1469?-1536?), poeta lírico e dramaturgo, dedicou-se a temas religiosos e a farsas, escritas em português e em espanhol. [RZ]

${ }^{27}$ Plauto (c. 254 a. C.-184 a. C.), criador da comédia latina, escreveu Anfitrião, Aululária e O soldado fanfarrão. [RZ]

${ }^{28}$ Em português, no original. Ferdinand Denis mantém a palavra em português nas oportunidades subseqüentes em que o termo aparece. [RZ]

${ }^{29}$ Francisco de Quevedo (1580-1645) é autor de El buscón, novela picaresca. [RZ]

${ }^{30}$ Lope de Vega (1562-1635) foi importante dramaturgo durante o Século de Ouro espanhol. [RZ]

${ }^{31}$ Erasmo de Rotterdam (1466-1536), teólogo e reformista, é autor de Elogio da loucura (1509). [RZ]

${ }^{32}$ Públio Terêncio Afer (185-159 a.C.), dramaturgo romano, é autor de O eunuco (161 a. C.) e Os irmãos (160 a. C.) [RZ] 
33 A Biblioteca Lusitana, de Diogo Barbosa Machado (1682-1772), foi a primeira bibliografia geral portuguesa, em quatro volumes, publicados em 1741, 1747, 1752 e 1759. [RZ]

${ }^{34}$ Friedrich Bouterwek (1765-1828) escreveu, entre 1801 e 1819, a História da poesia e da eloqüência, estando o quarto volume, editado em 1805, dedicado à literatura portuguesa. [RZ]

${ }^{35}$ No verbete dedicado a esse Gil Vicente, Diogo Barbosa Machado escreve: “Gil Vicente, natural de Lisboa, filho de Gil Vicente de quem se fez a memória precedente, e de Branca Bezerra. Não somente imitou, mas excedeu a seu pai na poesia cômica de tal sorte, que, para lhe não diminuir a glória que alcançara, foi causa de o mandar para a Índia onde mostrou em uma ação militar em que gloriosamente acabou a vida, que não era menos insigne na espada, que na pena." (MACHADO, Diogo Barbosa. Bibliotheca Lusitana. Biblioteca Virtual dos Descobrimentos Portugueses. v. 2, p. 384). [RZ]

${ }^{36}$ A referência a esse auto aparece na Biblioteca Lusitana, no verbete dedicado ao filho de Gil Vicente. Cf. MACHADO, Diogo Barbosa. Op. cit. [RZ]

${ }^{37}$ Francisco de Sá de Miranda (1481/1485?-1558?), poeta e comediógrafo, introduziu o novo estilo renascentista em Portugal. [RZ]

${ }^{38}$ Antônio Ferreira (1528 - 1569), poeta e dramaturgo, desenvolveu o movimento clássico iniciado por Sá de Miranda, contribuindo decisivamente para sua implantação em Portugal. [RZ]

${ }^{39}$ Quinto Horácio Flaco (65 a. C. - 8 a. C.), poeta lírico do período de Augusto, escreveu Odes, Sátiras e Epístolas. [RZ]

${ }^{40}$ Pero de Andrade Caminha (1520/1532-1589), poeta português do período renascentista, sofreu grande influência de Antônio Ferreira. [RZ]

${ }^{41}$ Diogo Bernardes (c. 1530-1595?), poeta lírico, pertenceu à geração de Sá de Miranda e Antônio Ferreira. Escreveu Várias rimas ao Bom Jesus (1594), Rimas várias - Flores do Lima (1597) e o Lima (1596). [RZ]

${ }^{42}$ Jerônimo Corte-Real (c. 1530-c. 1590) escreveu Sucesso do segundo cerco de Dio, de 1574, e Naufrágio e lastimoso sucesso da perdição de Manuel de Sousa Sepúlveda, de 1594. [RZ]

${ }^{43}$ Francisco Rodrigues Lobo (1573/1574?-1622?), poeta e prosador, escreveu A primavera, O pastorperegrino, $O$ desenganado, O Condestabre de Portugal e Éclogas. [RZ]

${ }^{44}$ D. Sebastião I (1554-1578) foi rei de Portugal após a morte de D. João III, em 1557, assumindo o trono na maioridade, em 1568. [RZ]

${ }^{45}$ Leão X, nascido Giovanni di Lorenzo de Medici (1475-1521), foi papa entre 1513 e 1521. [RZ]

${ }^{46}$ MIRANDA, Francisco de Sá de. “A El-Rei D. João.” In: __. Obras completas. Texto fixados, notas e prefácio de Rodrigues Lapa. 4. ed. revista. Lisboa: Sá da Costa, 1976. V. II, p. 39. [RZ]

${ }^{47}$ Francisco de Santo Agostinho Macedo (1596-1681), jesuíta e, depois, franciscano, é autor de Orpheus tragicocomoedia in aula regia palatii parisiensis coram rege christianissimo Ludovico XIV, de 1647, e de Diatriba de adventu S. Jacobi in Hispaniam, de 1662. [RZ]

${ }^{48}$ Antônio das Neves Pereira (17??-1818) comenta: "Não foi menos feliz o Sá de Miranda em duas comédias que nos deixou, a dos Estrangeiros, digo, e Os Vilhalpandos. Nem no seu estilo cômico há menos que admirar pela cópia de palavras, propriedade, e sal ático de expressão com que justamente enriqueceu nossa língua, e ornou este gênero de poesia pouco cultivado naqueles tempos não só entre nós, mas ainda entre os nossos vizinhos. Acha-se no seu estilo muita graciosidade liberal sazonada com pensamentos agudos e grande multidão de metáforas e alegorias, adágios, e axiomas, que são como antigos monumentos do gênio da Língua, variado com o gênio do Autor." PEREIRA, Antônio das Neves. "Ensaio sobre a filologia portuguesa por meio do exame e comparação de locução e estilo dos nossos mais insignes poetas, que floresceram no século XVI.” In:Memórias de literatura portuguesa. Lisboa: Academia Real das Ciências de Lisboa, 1792-1814. 8 t. p. 31. http:/ /purl.pt/194/ 1/ Acessado em 20 de maio de 2007. [RZ]

${ }^{49}$ Antônio Prestes (?-?), nascido em Santarém, escreveu os autos Avé-Maria, do Procurador, do Desembargador, dos Dois Irmãos, da Ciosa, do Mouro Encantado e das Cantarinhas. [RZ]

${ }^{50} \mathrm{O}$ nome correto do organizador é Afonso Lopes, "moço da Capela de sua Majestade", como informa a folha de rosto da obra, facsimilada em edição coordenada por Hernâni Cidade. Cf. Primeira parte dos autos e comédias portuguesas. Prefácio de Hernâni Cidade. Lisboa: Lysia, 1973. [RZ]

${ }^{51}$ Sebastião Pires (?-?) produziu o Auto da bela menina, além das obras que teriam sido impressas em 1557: $A$ nau do filho de Deus e Silvério. [RZ] 
${ }^{52}$ Antônio Ribeiro Chiado (? - 1591) é autor de Auto da natural invenção, Auto das regateiras, Prática de compadres e Prática de oito figuras. [RZ]

${ }^{53}$ Simão Machado (1570-1640) é autor de Cerco de Diu e Comédia da Pastora Alfea. [RZ]

${ }^{54}$ Jorge Ferreira de Vasconcelos (1515-1585) é autor de Comédia Eufrósina (1542-1543), Ulisipo (1561) e Comédia Aulegrafia, publicada postumamente em 1615. [RZ]

${ }^{55}$ É provável que Ferreira devesse este gosto pelos antigos a Buchanan, professor em Coimbra à época em que o poeta aí estudava, assim como Camões. O sábio escocês, amigo dos irmãos Gouveias, de Diogo de Teive e de outros portugueses que se encontravam no colégio de Santa Bárbara, em Paris, foi chamado, com eles, por D. João III, para ocupar uma cadeira de humanidades e de filosofia. Verdier fala disso nas excelentes notas com que enriqueceu o poema português $O$ bissope, e pensa que os autores célebres do tempo devem muito a ele. Buchanan traduziu para o latim a Medéia e o Alceste de Eurípedes; compôs na mesma língua duas tragédias intituladas Jefté e João Batista. [George Buchanan (1506-1582), humanista escocês, destacou-se como autor dramático, tendo escrito as tragédias The Baptist e Jephtha; Diogo de Teive (c. 1514-depois de 1565), escritor quinhentista, esteve ligado ao Humanismo português da época de D. João III. Estudou no Colégio de Santa Bárbara em Paris, tendo retornado a Portugal para lecionar no então recém fundado Colégio das Artes, da Universidade de Coimbra; André de Gouveia (1497-1548) foi professor no Colégio de Santa Bárbara, em Paris, e do Colégio da Guiena, em Bordéus, célebre à sua época. A convite de D. João III, participou, em 1547, da fundação do Colégio das Artes, na Universidade de Coimbra. Antônio de Gouveia (c. 1513-1566) começou a carreira docente no Colégio de Santa Bárbara e atuou em várias instituições de ensino na França do século XVI; Antônio Dinis da Cruz e Silva (1731-1799), fundador da Arcádia Lusitana, escreveu o poema herói-cômico $O$ hissope, que satiriza questões da Igreja em Portugal; Timothée Lecussan-Verdier (1754?-1831) traduziu O hissope para o francês, versão publicada ao final do século XVIII; Eurípedes (c. 485 a.C.-406 a. C), dramaturgo grego, é autor de Medéia, Alceste, Electra, Hipólito, entre outras tragédias. [RZ]

${ }^{56}$ Sófocles (496a. C.?-406 a. C.), dramaturgo grego, é autor de Édipo Rei e Antígona, entre outras tragédias. [RZ] ${ }^{57}$ FERREIRA, Antonio. O cioso. In:___. Poemas lusitanos. Segunda impressão emendada e acrescentada com a vida e comédias do mesmo poeta. Lisboa: Régia Oficina Tipográfica, 1771. Tomo II, p. 89. [RZ]

${ }^{58}$ Trecho da fala de Euclião, protagonista de $A$ aululária, de Plauto. [RZ]

${ }^{59}$ Pensa-se também que, ao compor sua primeira peça, ele teve a intenção de recriminar a Felipe II, assassino de seu filho.

${ }^{60}$ CAMÕES, Luís de. El-Rei Seleuco. In: __. Obras completas. Autos-comédias. Segunda parte. Rio de Janeiro: Nova Aguilar, 1963. p. 772. [RZ]

${ }^{61}$ Molière (1622-1673), dramaturgo francês, é autor de Escola de mulheres (1662), Tartufo (1664), O avarento (1668) e Anfitrião (1668), entre outras comédias. [RZ]

${ }^{62}$ D João IV (1604-1656) restaurou a independência portuguesa em 1640, após sessenta anos de dominação espanhola. [RZ]

${ }^{63}$ Luís XIV (1638-1715) foi rei da França entre 1643-1715, período conhecido como o “grande século”. [RZ]

${ }^{64}$ Fernando de Menezes (1614-1699), segundo Conde de Ericeira, escreveu Vida e ações de el-rei D. João I, oferecida à memória póstuma do Serenissimo Principe D. Theodosio, de 1677. [RZ]

${ }^{65}$ Francisco Xavier de Menezes (1673-1743), quarto Conde de Ericeira, militar, historiador, crítico literário e orador, traduziu a Arte poética, de Boileau, autor com quem se correspondia, e escreveu Historia do Imperador Carlos V. [RZ]

${ }^{66}$ Antônio José da Silva (1705-1739), conhecido como O Judeu, cuja obra foi reunida no livro Teatro cômico português, morreu em auto-de-fé, em Lisboa. [RZ]

${ }^{67}$ Miguel Tibério Pedegache Brandão Ivo (1730?-1794) é autor das tragédias Mégara e Nova Castro. [RZ]

${ }^{68}$ Domingos dos Reis Quita (1728 - 1770), poeta arcádico, escreveu as tragédias Mégara, Hermíone, Astarto e Castro. [RZ]

${ }^{69}$ Pedro Antônio Joaquim Correia Garção (1724 - 1772?), poeta e dramaturgo, foi um dos fundadores, em 1757, da Arcádia Lusitana. [RZ]

${ }^{70}$ Trata-se da Cantata de Dido. [RZ]

${ }^{71}$ Trata-se de Teresa de Melo Breyner (1739-depois de 1798), cuja tragédia, Osmia, foi premiada pela Academia Real das Ciências em 1788. [RZ] 
${ }^{72}$ Jean-Charles-Léonard Simonde de Sismondi (1773-1842) publicou De la littérature du Midi de l'Europe, em 1813, dedicando os últimos cinco capítulos à literatura portuguesa. Os comentários de Sismondi localizam-se entre as páginas 543 e 555 do tomo IV, daquela obra. [RZ]

${ }^{73}$ João Batista Gomes Junior (c. 1775-1803) é autor da Nova Castro, de 1806, que obteve grande acolhida do público português. [RZ]

${ }^{74}$ A tragédia O triunfo da natureza, de 1809, foi escrita por Vicente Pedro Nolasco da Cunha (1773-18??). [RZ]

${ }^{75}$ A tragédia D. Sebastião em Africa foi escrita por Manuel Caetano Pimenta de Aguiar (1765-1832) e publicada em 1817. [RZ]

${ }^{76}$ A tragédia Catão, de Almeida Garrett (1799-1854) foi publicada em 1822. [RZ]

${ }^{77}$ Ferdinand Denis assistiu às representações dessas peças, que talvez não tenham sido publicadas, razão porque os autores dos textos e os títulos originais não foram localizados. [RZ]

${ }^{78}$ Encontram-se, na Coleção de obras dramáticas, de Antônio Joaquim de Carvalho, três peças deste gênero, intuladas: A velhice namorada; Aula de toureiros tolos; O galego bruto e moço. O mesmo autor escreveu uma comédia conhecida sob o título de $A$ ribeira do peixe, ou A peixeira virtuosa. [O livro de Antônio Joaquim Carvalho (?-1817) foi publicado em Lisboa, em 1813. RZ] 


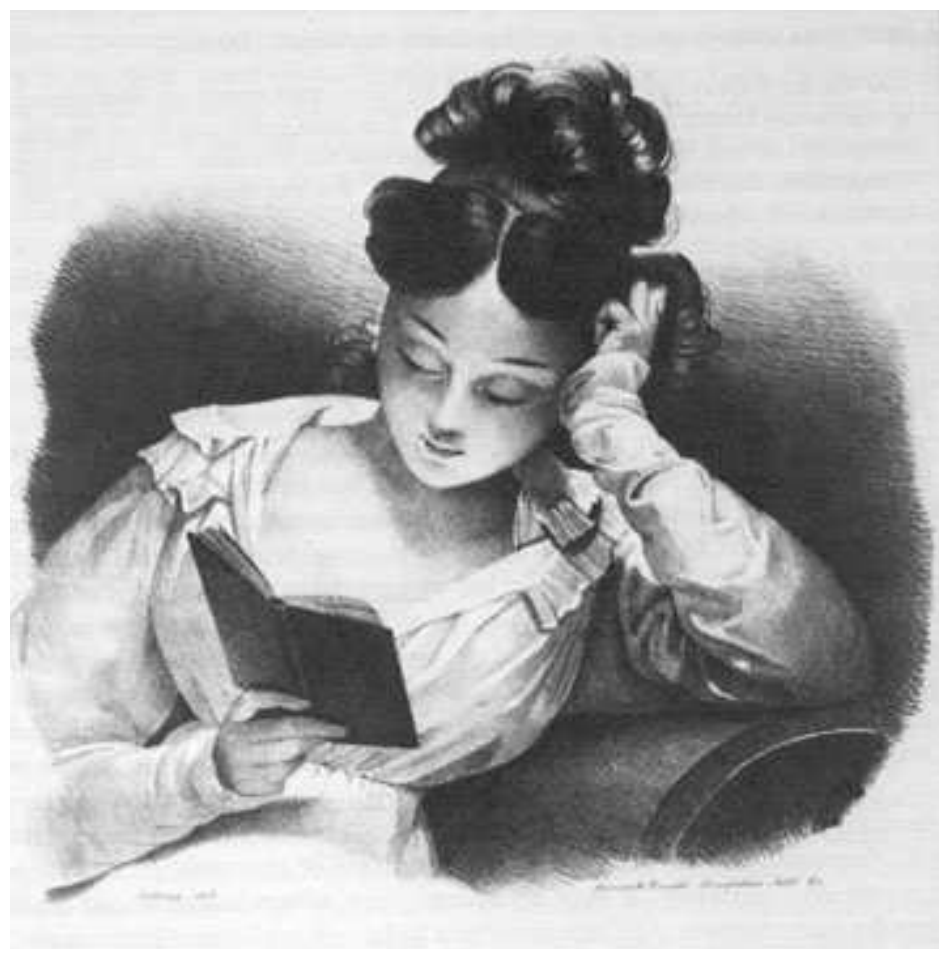

